\title{
CUADRAGÉSIMO ANIVERSARIO DE LA REVISTA DE FILOLOGÍA Y LINGÜÍSTICA
}

El 1 de mayo de 1975 salió publicado el primer número del primer volumen de la Revista de Filología y Lingüística de la Universidad de Costa Rica. Este primer número fue editado en la Editorial Fernández Arce y su edición estuvo a cargo del primer Director que tuvo la Revista, el Dr. Jézer González Picado, quien también fue uno de sus más entusiastas gestores.

El Consejo Editorial de la Revista en ese entonces estaba conformado por distinguidos profesores e investigadores de la Escuela de Filología de esta misma casa de estudios: Arturo Agüero, Jorge Blanco, Clara Cornelli, Manuel Antonio González, Manuel Picado, Elsa Orozco, Dorothy Stark y Jack Wilson.

En este primer número, Arturo Agüero escribe una corta presentación, en la que dedica el número a la memoria del Dr. Pierre Fouché, profesor de la Sorbona, quien fue el primer docente de Filología Románica y Lingüística de la Universidad de Costa Rica en 1961. Un extracto de esta presentación refleja el espíritu de esta época pionera y retrata los avatares que nos enseñan el tesón y la visión de quienes contribuyeron a forjar lo que hoy es nuestra universidad.

\footnotetext{
Desde hace cuatro años los profesores de Filología y Lingüística de la Universidad de Costa Rica consideraron que ya era oportuno publicar una Revista con el fin de dar a conocer estimables trabajos elaborados por algunos y tuvieran así más provecho. Sin embargo, no es sino hasta hoy cuando se cumple ese anhelo, con la publicación del primer número de la Revista de Filología y Lingüística, la cual aspira a contribuir al desarrollo de las disciplinas correspondientes.

Así mismo se ha considerado que los estudiantes universitarios podrían encontrar aquí cierta información complementaria de una manera tal vez más directa y expedita que en las bibliotecas, de modo que esta publicación tendría, en cierta medida, un sentido didáctico.

Es justo consignar nuestro reconocimiento a dos estimables profesores, el Dr. Domenico Vitola y el Dr. Mario Palacios. Ellos donaron durante un año, el sueldo devengado en sendos cursos, y así se obtuvo el dinero con que se ha pagado la edición de este primer número de la Revista.
}

Este primer número contenía 81 páginas a doble columna y se publicaron en él siete artículos:

- Hombres de maíz, trascendentalización de la existencia de Virginia Sandoval.

- Trayectoria poética de Jorge Debravo de Manuel Picado.

- Vida de las palabras de Manuel Antonio Quirós.

- Pedro Páramo: sus contenidos y formas en relación con la novela hispanoamericana en general y con la mejicana en particular de Jézer González.

- Apuntes críticos sobre la poesía de Roberto Brenes Mesén, en busca de un esquema poético de Jorge Andrés Camacho.

- La mostración lingüística y la autonomía sintáctica de Gastón Gaínza.

- Alcances en torno a la problemática del narrador de Enrique Margery. 
Con el paso del tiempo cambia los intereses, las temáticas, las teorías. Y una revista también refleja este continuo cambio: es un retrato del espíritu de las épocas.

Sin embargo, en este volumen conmemorativo, hemos querido retomar los temas que fueron tratados en aquel primer número de la Revista de Filología y Lingüística, como un homenaje a quienes inauguraron, con sus ensayos, nuestra publicación. Por ello, hemos invitado a algunos investigadores de reconocida trayectoria de la Universidad de Costa Rica a que escribieran artículos sobre estas mismas materias, pero a la luz de los intereses, teorías y métodos actuales. 